medRxiv preprint doi: https://doi.org/10.1101/2020.06.07.20124701; this version posted November 2, 2020. The copyright holder for this preprint

(which was not certified by peer review) is the author/funder, who has granted medRxiv a license to display the preprint in perpetuity.

This article is a US Government work. It is not subject to copyright under 17 USC 105 and is also made available for use under a CCO license.

\title{
1 Duration and reliability of the silent period in individuals with spinal cord injury
}

2 Running title: Silent period in cervical SCI

3 Hannah Sfreddo ${ }^{a *}$, Jaclyn R. Wecht ${ }^{a *}$, Ola Alsalman ${ }^{a, b}$, Yu-Kuang Wu ${ }^{a, b}$, Noam Y. Harel ${ }^{a, b}$

4

$5 \quad$ * These authors contributed equally to this work

6

7 a, James J. Peters VA Medical Center, 130 West Kingsbridge Road, Bronx, New York 10468

8 USA

9 b, Icahn School of Medicine at Mount Sinai, 1 Gustave L. Levy Place, New York, New York

1010029 USA

11

12 Corresponding Author:

13 Noam Y. Harel, MD, PhD

14 718-584-9000 x1742 (p); 888-299-1965 (f); noam.harel@mssm.edu 
medRxiv preprint doi: https://doi.org/10.1101/2020.06.07.20124701; this version posted November 2, 2020. The copyright holder for this preprint (which was not certified by peer review) is the author/funder, who has granted medRxiv a license to display the preprint in perpetuity. This article is a US Government work. It is not subject to copyright under 17 USC 105 and is also made available for use under a CCO license.

16 Design: Observational.

17 Objectives: We aim to better understand the silent period (SP), an inhibitory counterpart to the

18 well-known motor evoked potential (MEP) elicited by transcranial magnetic stimulation (TMS), in

19 individuals with spinal cord injury (SCI).

20 Setting: Veterans Affairs Hospital in New York.

21 Methods: Electromyographic responses were measured in the target abductor pollicis brevis at

22 rest (TMS at $120 \%$ of resting motor threshold $(\mathrm{RMT})$ ) and during maximal effort (TMS at $110 \%$

23 of RMT). Participants with chronic cervical SCl $(n=9)$ and able-bodied volunteers $(n=12)$

24 underwent between 3-7 sessions of stimulation on separate days. The primary outcomes were

25 the magnitude and reliability of SP duration, resting and active MEP amplitudes, and RMT.

26 Results: SCI participants showed significantly lower MEP amplitudes compared to AB

27 participants. SCI SP duration was not significantly different from AB SP duration. SP duration

28 demonstrated reduced intra-participant variability within and across sessions compared with

29 MEP amplitudes. SCI participants also demonstrated a higher prevalence of SP 'interruptions'

30 compared to AB participants.

31 Conclusions: SP reflects a balance between corticospinal excitatory and inhibitory processes.

32 SP duration is more reliable within and across multiple sessions than MEP amplitude.

34 Keywords: Transcranial magnetic stimulation, motor evoked potential, silent period, spinal cord

35 injury, reliability 
medRxiv preprint doi: https://doi.org/10.1101/2020.06.07.20124701; this version posted November 2, 2020. The copyright holder for this preprint (which was not certified by peer review) is the author/funder, who has granted medRxiv a license to display the preprint in perpetuity. This article is a US Government work. It is not subject to copyright under 17 USC 105 and is also made available for use under a CCO license.

\section{Introduction}

38 The motor evoked potential (MEP) amplitude in response to transcranial magnetic stimulation

39 (TMS) is one of the most commonly used outcome measures for tracking neurophysiology of

40 the corticospinal system. Spinal cord injury (SCI) reduces MEP amplitude in muscles below the

41 injury, reflecting reduced excitatory transmission across the spinal lesion. In contrast,

42 corticospinal inhibitory processes are comparatively understudied after SCI. The silent period

43 (SP) occurs upon TMS administration to the motor cortex during volitional contraction of a target

44 muscle on either the ipsilateral or contralateral side of stimulation. In contralateral SP elicitation,

45 the resulting MEP is followed by a period of electromyographic (EMG) suppression (silent

46 period) usually lasting 100-300 milliseconds ${ }^{1-3}$ (Figure 1). Whereas the ipsilateral SP depends

47 on corpus callosum-mediated interhemispheric inhibition, the contralateral SP reflects cortical

48 and corticospinal processes ${ }^{3,4}$.

50 Spinal inhibitory mechanisms contribute to the first $\sim 50 \mathrm{~ms}$ of the SP through hyperpolarization

51 and segmental recurrent inhibition of motor neurons ${ }^{1,3}$. Interneuronal gamma-aminobutyric acid

$52(\mathrm{GABA})_{\mathrm{B}}$ plays a major role in mediating intracortical inhibition of pyramidal motor cortex

53 neurons during the remainder of the $\mathrm{SP}^{2,5}$. This is most clearly demonstrated by the elongation

54 of SP duration when baclofen, a specific GABA $_{B}$ receptor agonist, is delivered intrathecally ${ }^{6}$.

55 However, studies of oral and intravenous baclofen have failed to demonstrate a significant effect 56 on SP duration ${ }^{5,7,8}$. 
medRxiv preprint doi: https://doi.org/10.1101/2020.06.07.20124701; this version posted November 2, 2020. The copyright holder for this preprint

(which was not certified by peer review) is the author/funder, who has granted medRxiv a license to display the preprint in perpetuity.

This article is a US Government work. It is not subject to copyright under 17 USC 105 and is also made available for use under a CCO license.

58 Lesions of the nervous system may lengthen or shorten SP duration. Cerebral pathologies that

59 lengthen SP include stroke ${ }^{9}$, epilepsy ${ }^{10}$, and depression ${ }^{11}$. Conversely, pathologies that shorten

60 SP include bipolar disorder ${ }^{12}$ and chronic neuropathic pain ${ }^{13}$.

61

62 Few prior studies have investigated SP in the SCI population, with mixed results ${ }^{7,14-17}$. It is not

63 yet fully elucidated whether SCI lengthens SP (perhaps due to decreased afferent feedback

64 from the periphery) or shortens SP (perhaps due to increased cortical or spinal segmental

65 excitability). Furthermore, the reliability of SP duration as an outcome metric in SCI relative to

66 the more commonly used MEP amplitude is hardly known ${ }^{18}$. To further characterize this

67 potentially important neurophysiological measure in the SCI population, we compared

68 magnitude and variability of hand muscle SP durations, MEP thresholds, and MEP amplitudes

69 in individuals with chronic cervical SCI and able-bodied volunteers across multiple testing

70 sessions.

\section{Methods}

74 2.1 Design - This experiment was an exploratory post-hoc analysis of a larger study in which

75 we tested a novel configuration for non-invasive cervical transcutaneous spinal stimulation in

76 individuals with and without cervical SCI (clinicaltrials.gov NCT02469675) ${ }^{19}$. SCI participants

77 were eligible if they had traumatic or non-traumatic SCl between segments $\mathrm{C} 2-\mathrm{C} 8$ with any

78 evidence for partially retained movement of finger extension, finger flexion, or finger abduction

79 of either hand. Potential participants were excluded if they had risk factors for seizures or if they 
medRxiv preprint doi: https://doi.org/10.1101/2020.06.07.20124701; this version posted November 2, 2020. The copyright holder for this preprint (which was not certified by peer review) is the author/funder, who has granted medRxiv a license to display the preprint in perpetuity. This article is a US Government work. It is not subject to copyright under 17 USC 105 and is also made available for use under a CCO license.

80 had frequent episodes of autonomic dysreflexia. Participants provided informed consent before

81 initiating testing. All procedures were approved by the Institutional Review Board of the James

82 J. Peters VA Medical Center, Bronx, NY. All applicable institutional and governmental

83 regulations concerning the ethical participation of human volunteers were followed during this

84 research.

2.3 General Procedure - Neurological examination of motor and sensory function was

87 performed according to the International Standards for the Neurological Classification of Spinal

88 Cord Injury (ISNCSCI). Sessions were performed on separate days at a consistent time of day

89 per participant. Stimulation was delivered with participants in a seated upright position in an

90 adjustable TMS treatment chair (Magventure), or for one participant, in her own wheelchair. For

91 participants without neurological injury, TMS was targeted toward the dominant hand. For those

92 with SCI, TMS was targeted toward the hand with lower motor thresholds and more consistent

93 electrophysiological responses to central and peripheral stimulation. Arms and hands were

94 pronated and relaxed on a cushion placed in the participant's lap. Participants were not asked to

95 withhold their routine daily medications.

96

97 2.4 Transcranial Magnetic Stimulation (TMS) - A MagPro R30 or X100 system (Magventure,

98 Farum Denmark) with $80 \mathrm{~mm}$ winged coil (D-B80) was used. The magnet was oriented at a 45-

99 degree angle from the sagittal plane, centered over the hand motor cortex hotspot for maximal

100 APB response. The first six participants wore reusable cloth headcaps upon which the hotspot

101 was labeled with a marker in relation to the vertex. Our laboratory obtained an optical-based 
medRxiv preprint doi: https://doi.org/10.1101/2020.06.07.20124701; this version posted November 2, 2020. The copyright holder for this preprint (which was not certified by peer review) is the author/funder, who has granted medRxiv a license to display the preprint in perpetuity. This article is a US Government work. It is not subject to copyright under 17 USC 105 and is also made available for use under a CCO license.

102 neural navigation system (Brainsight, Rogue Research, Montreal, Canada) that was used to

103 track hotspots for the final 15 participants. There was no significant difference in session-to-

104 session variability of any TMS measure with or without neural navigation. RMT was determined

105 as the percent of maximal stimulator output required to elicit an MEP in the APB muscle of at 106 least $50 \mu \mathrm{V}$ in 5 out of 10 repetitions.

107

1082.5 Electromyographic Data - EMG of the target APB was recorded using surface sensors 109 with 300x preamplification, $15-2,000 \mathrm{~Hz}$ bandwidth, and internal grounding (Motion Lab Systems

110 Z03-002, Baton Rouge, Louisiana, USA). EMG was collected at a sample rate of 5,000 $\mathrm{Hz}$ via

111 digital acquisition board and customized LabVIEW software (National Instruments USB-6363,

112 Austin, Texas, USA). All EMG data were acquired and quantified using custom LabVIEW 113 scripts.

114

1152.6 Eliciting and Measuring the Silent Period (SP) - While participants pinched a 116 dynamometer (Tracker Freedom, J-Tech, Salt Lake City, Utah, USA) between their thumb and 117 third finger using maximal effort, a single biphasic TMS pulse was delivered over the hand 118 motor cortex hotspot at $110 \%$ of each participant's RMT. The resulting MEP amplitude and SP

119 duration in the contralateral APB muscle were measured. Five to six replicates were performed 120 per session, with care taken to avoid fatigue between replicates. Participants completed 7 121 sessions on different days involving SP, apart from three individuals who withdrew from the 122 study before completion (one AB participant completed 6 sessions, one $\mathrm{SCl}$ participant 123 completed 3 sessions, and one SCI participant completed 2 sessions). 
medRxiv preprint doi: https://doi.org/10.1101/2020.06.07.20124701; this version posted November 2, 2020. The copyright holder for this preprint (which was not certified by peer review) is the author/funder, who has granted medRxiv a license to display the preprint in perpetuity. This article is a US Government work. It is not subject to copyright under 17 USC 105 and is also made available for use under a CCO license.

124 To quantify $\mathrm{SP}_{\mathrm{DUR}}$, SP onset was visually defined as the end of the TMS-induced MEP, and SP

125 offset was visually defined as the earliest resumption of pre-TMS EMG activity ${ }^{3}$ (Figure 1).

126 We defined an "SP interruption" as a spike in EMG activity surrounded by SP silence, where the

127 duration of interruption was less than $20 \mathrm{~ms}$, and the absolute amplitude from one peak to the 128 adjacent trough was at least $25 \%$ of the largest amplitude found during the 100 ms preceding 129 the TMS impulse.

1302.7 Analysis - $\underline{\text { Outcomes: }}$ The primary dependent variables were MEP amplitude $(\mathrm{mV})$ at rest 131 (MEP REST $_{1}$ ) and during SP elicitation (MEP ACTIVE$)$, SP duration (ms) (SP DUR , and RMT (\% 132 maximum stimulator output). SP interruptions were an exploratory outcome. For each 133 participant, within-session means were computed from the 5-6 replicates of each test, then 134 averaged across sessions. Before group comparisons, each outcome was first tested for 135 normality using the Shapiro-Wilks test. Normally distributed values (MEP ACTIVE, SP DUR, and $136 \mathrm{RMT}$ ) were compared between $\mathrm{AB}$ and $\mathrm{SCl}$ groups using independent-sample t-tests. Non-

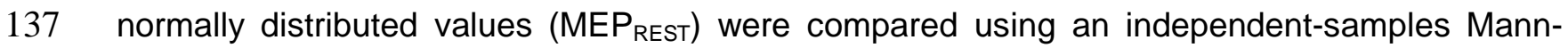
138 Whitney U test.

140 Variability: Within-session coefficients of variation (CV) were computed for each participant from

141 the 5-6 replicates of each test, then averaged across sessions ${ }^{20}$. Note that RMT was only 142 determined once per session, so it was not possible to determine within-session RMT variability. 143 Between-session CVs were computed from the session means of each test. CVs were then 144 averaged across participants within each group. As CV values were not normally distributed, the 
medRxiv preprint doi: https://doi.org/10.1101/2020.06.07.20124701; this version posted November 2, 2020. The copyright holder for this preprint (which was not certified by peer review) is the author/funder, who has granted medRxiv a license to display the preprint in perpetuity. This article is a US Government work. It is not subject to copyright under 17 USC 105 and is also made available for use under a CCO license.

145 non-parametric related-samples Friedman's two-way analysis of variance by ranks test was

146 applied to compare CVs across outcomes within each group. Significant values on Friedman's

147 test were analyzed post-hoc between pairs of outcomes using related-samples Wilcoxon signed

148 rank tests.

149

150 Interruptions: A chi-squared test was used to compare the frequency of participants with

151 interrupted SPs between groups. As interruption values were not normally distributed, the non-

152 parametric Mann-Whitney $U$ test was used to compare number of interruptions per participant

153 between groups.

154

155 Due to testing multiple comparisons, a p value of $<0.01$ was used to determine significance.

157 Excel (Microsoft, Redmond, Washington, USA) and SPSS Version 25 (IBM, Armonk, New York, 158 USA) were used for all analyses.

159

160 Individual-level data is included as Supplementary Data 1 (by participant, averaged across 161 sessions) and Supplementary Data 2 (by participant per session). 
medRxiv preprint doi: https://doi.org/10.1101/2020.06.07.20124701; this version posted November 2, 2020. The copyright holder for this preprint (which was not certified by peer review) is the author/funder, who has granted medRxiv a license to display the preprint in perpetuity.

This article is a US Government work. It is not subject to copyright under 17 USC 105 and is also made available for use under a CCO license.

3.1 Participants - 21 individuals (12 $\mathrm{AB}$ and $9 \mathrm{SCl} ; 17$ males, 4 females) participated in this

167 study (Table 1). Participants ranged in age from 22 to 64 years old. Of the $9 \mathrm{SCl}$ participants,

168 eight had traumatic SCI, one had idiopathic transverse myelitis.

\section{Table 1A - SCI Demographics}

\begin{tabular}{|c|c|c|c|c|c|c|c|}
\hline ID & Gender & Age & $\begin{array}{l}\text { Etiology } \\
\text { of Injury }\end{array}$ & $\begin{array}{c}\text { DOI } \\
\text { (Years) }\end{array}$ & LOI & $\begin{array}{l}\text { ISNCSCI } \\
\text { Grade }\end{array}$ & $\begin{array}{c}\text { TMS } \\
\text { Threshold } \\
\text { (\% MSO) }\end{array}$ \\
\hline 1 & $M$ & 29 & $\mathrm{~T}$ & 3 & C8 & C & 45.9 \\
\hline 2 & $M$ & 52 & $\mathrm{~T}$ & 17 & C8 & C & 35.8 \\
\hline 18 & $\mathrm{M}$ & 64 & $\mathrm{~T}$ & 14 & $\mathrm{C} 4$ & D & 59.4 \\
\hline 23 & $M$ & 57 & $\mathrm{~T}$ & 12 & C4 & D & 60.8 \\
\hline 27 & $M$ & 40 & $\bar{T}$ & 14 & C4 & $\mathrm{D}$ & 69.7 \\
\hline 28 & $M$ & 42 & $T$ & 16 & C5 & D & 65.9 \\
\hline 31 & $M$ & 54 & $\mathrm{~T}$ & 6 & C5 & C & 52.7 \\
\hline 34 & $F$ & 52 & $\mathrm{~T}$ & 16 & C4 & $B$ & 72.0 \\
\hline 39 & $\mathrm{~F}$ & 22 & NT & 1 & C5 & C & 30.0 \\
\hline Totals & $7 \mathrm{M}, 2 \mathrm{~F}$ & $\begin{array}{c}45.8 \\
(22-64)\end{array}$ & 8T, 1NT & $\begin{array}{c}11 \\
(1-17)\end{array}$ & C4-C8 & 1B, 4C, 4D & $\begin{array}{c}54.7 \\
(30.0-72.0)\end{array}$ \\
\hline
\end{tabular}

171

\section{Table 1B - AB Demographics}




\begin{tabular}{|c|c|c|c|}
\hline ID & Gender & Age & $\begin{array}{c}\text { TMS Threshold } \\
\text { (\% MSO) }\end{array}$ \\
\hline 5 & $M$ & 25 & 35.1 \\
\hline 8 & $M$ & 27 & 34.1 \\
\hline 9 & $M$ & 44 & 35.9 \\
\hline 11 & $F$ & 22 & 38.2 \\
\hline 12 & $F$ & 23 & 30.6 \\
\hline 14 & $M$ & 44 & 32.6 \\
\hline 15 & $M$ & 45 & 44.4 \\
\hline 16 & $M$ & 24 & 52.3 \\
\hline 22 & $M$ & 58 & 53.9 \\
\hline 25 & $M$ & 55 & 41.9 \\
\hline 36 & $M$ & 23 & 32.6 \\
\hline 38 & $M$ & 22 & 53.0 \\
\hline Totals & $10 M, 2 F$ & $34.3(22-58)$ & $40.4(30.6-53.9)$ \\
\hline
\end{tabular}

173 Table 1. Participant demographics. A) SCI. Etiology of Injury - traumatic (T) or not traumatic

174 (NT); DOI - duration of injury; LOI - neurological level of injury; ISNCSCI - International

175 Standards for the Neurological Classification of SCI; \%MSO - percent of maximal stimulator

176 output (average across sessions). B) AB.

177 
medRxiv preprint doi: https://doi.org/10.1101/2020.06.07.20124701; this version posted November 2, 2020. The copyright holder for this preprint (which was not certified by peer review) is the author/funder, who has granted medRxiv a license to display the preprint in perpetuity. This article is a US Government work. It is not subject to copyright under 17 USC 105 and is also made available for use under a CCO license.

3.2 SP duration - SCI participants had mean (SEM) SP duration of 111.40 (18.39) ms; range 46.90 - $216.17 \mathrm{~ms}$, whereas AB participants had SP duration of 97.99 (9.88) ms; range 35.30 -

$181 \quad 152.86$ ms (non-significant, independent-sample t-test) (Table 2).

$182 \quad 3.3$ Resting motor threshold - SCI participants showed a tendency toward higher mean 183 (SEM) RMTs (54.69 (4.94)\% maximum stimulator output; range 30.0 - 72.0) than $A B$ 184 participants $(40.37(2.48) \%$ maximum stimulator output, range 30.6 - 53.9) $(p=0.012$, 185 independent-sample t-test) (Table 2).

3.4 MEP amplitudes - SCI participants showed significantly lower mean (SEM) MEP REST

187 amplitudes $(0.148(0.018) \mathrm{mV})$ than $\mathrm{AB}$ participants $(0.462(0.094) \mathrm{mV})(\mathrm{p}<0.0005$ independent-

188 samples Mann-Whitney $U$ test). SCI participants showed significantly lower MEPACTIVE 189 amplitudes $(0.700(0.133) \mathrm{mV})$ than $\mathrm{AB}$ participants $(2.305(0.233) \mathrm{mV})(\mathrm{p}<0.0005$ independent190 sample t-test) (Table 2).

192 Table 2

\begin{tabular}{|ccc|}
\hline Outcome & AB $(\mathbf{n = 1 2})$ & SCI $(\mathbf{n}=9)$ \\
\hline RMT (\% & $40.37(2.48)$ & $54.69(4.94)$ \\
MSO) & & \\
\hline SP & & \\
(mS) & $97.99(9.88)$ & $111.4(18.39)$ \\
\hline MEP & & $0.148(0.018)$ \\
\hline
\end{tabular}




\begin{tabular}{|c|c|c|}
\hline$(m V)^{\star}$ & & \\
\hline MEP $_{\text {ACTIVE }}$ & & \\
\hline$(m V)$ * & $2.305(0.233)$ & $0.700(0.133)$ \\
\hline
\end{tabular}

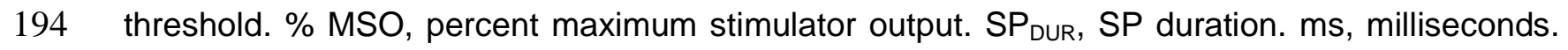

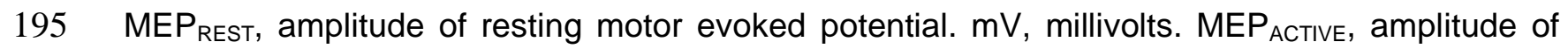
196 active motor evoked potential. *, statistically significant between-group difference.

3.5 Intraindividual variability within sessions (Table 3, Figure $2 A$ ) - In AB volunteers, the

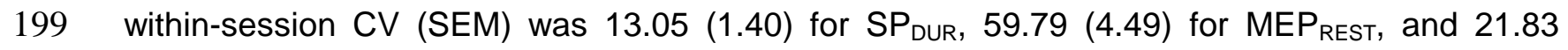

200 (1.78) for MEP ACTIVE $(p<0.0005$ on related-samples Friedman's two-way analysis of variance by

201 ranks test). Post hoc pairwise comparisons showed that SP DUR had significantly lower within-

202 session $C V$ than both $\operatorname{MEP}_{\text {REST }}(\mathrm{p}=0.002$ on related-samples Wilcoxon signed rank test) and

$203 \operatorname{MEP}_{\text {ACTIVE }}(\mathrm{p}=0.005$ on related-samples Wilcoxon signed rank test). In SCI participants, the CV

204 was 16.08 (2.56) for $\mathrm{SP}_{\mathrm{DUR}}, 52.93$ (6.18) for $\mathrm{MEP}_{\mathrm{REST}}$, and 28.38 (2.64) for MEP $\mathrm{ACTIVE}_{(\mathrm{p}<0.0005}$

205 on related-samples Friedman's two-way analysis of variance by ranks test). Post hoc pairwise

206 comparisons showed that $\mathrm{SP}_{\mathrm{DUR}}$ had significantly lower within-session $\mathrm{CV}$ than MEP $\mathrm{REST}$

$207(p=0.008$ on related-samples Wilcoxon signed rank test) but not MEP ACTIVE $(p=0.028$ on related-

208 samples Wilcoxon signed rank test). Thus, SP DUR has lower within-session variability than MEP

209 amplitudes in both able-bodied and SCI individuals. Variability did not significantly differ

210 between $\mathrm{AB}$ and $\mathrm{SCl}$ groups. 
medRxiv preprint doi: https://doi.org/10.1101/2020.06.07.20124701; this version posted November 2, 2020. The copyright holder for this preprint (which was not certified by peer review) is the author/funder, who has granted medRxiv a license to display the preprint in perpetuity. This article is a US Government work. It is not subject to copyright under 17 USC 105 and is also made available for use under a CCO license.

212 Table 3

\begin{tabular}{|c|c|c|c|}
\hline Outcome & Group & Within-session & $\begin{array}{l}\text { Between- } \\
\text { session }\end{array}$ \\
\hline RMT & $\begin{array}{l}\mathrm{AB} \\
\mathrm{SCl}\end{array}$ & & $\begin{array}{l}6.96(0.69) \\
9.19(1.21)\end{array}$ \\
\hline$S P_{\text {DUR }}$ & $\begin{array}{l}\mathrm{AB} \\
\mathrm{SCl}\end{array}$ & $\begin{array}{l}13.05(1.40) \\
16.08(2.56)\end{array}$ & $\begin{array}{l}19.61(2.67) \ddagger \\
28.50(5.30) \ddagger\end{array}$ \\
\hline MEP $_{\text {REST }}$ & $\begin{array}{l}\mathrm{AB} \\
\mathrm{SCl}\end{array}$ & $\begin{array}{l}59.79(4.49) \text { * } \\
52.93(6.18) \text { * }\end{array}$ & $\begin{array}{c}\mathbf{5 2 . 0 4 ( 6 . 3 2 ) { } ^ { * }} ¥ \\
45.08(6.90)\end{array}$ \\
\hline MEP $_{\text {ACTIVE }}$ & $\begin{array}{l}A B \\
S C l\end{array}$ & $\begin{array}{l}21.83(1.78) \text { * } \\
28.38(2.64)\end{array}$ & $\begin{array}{l}33.58(4.12) \ddagger \\
35.06(3.63) \ddagger\end{array}$ \\
\hline
\end{tabular}

213 Table 3 - Outcome variability. Coefficients of variation (S.E.M.) for AB and SCl groups. *,

214 statistically significant difference between SP $_{\text {DUR }}$ and other outcomes within each group. $¥$,

215 statistically significant difference between RMT and other outcomes within each group. 
medRxiv preprint doi: https://doi.org/10.1101/2020.06.07.20124701; this version posted November 2, 2020. The copyright holder for this preprint (which was not certified by peer review) is the author/funder, who has granted medRxiv a license to display the preprint in perpetuity. This article is a US Government work. It is not subject to copyright under 17 USC 105 and is also made available for use under a CCO license.

$217 \quad 3.6$ Intraindividual variability across sessions (Table 3, Figure 2B) - In AB volunteers, the

218 between-session CV was 19.61 (2.67) for $\mathrm{SP}_{\mathrm{DUR}}, 52.04$ (6.32) for $\mathrm{MEP}_{\mathrm{REST}}, 33.58$ (4.12) for

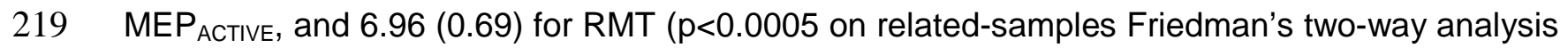

220 of variance by ranks test). Post hoc pairwise comparisons showed that $\mathrm{SP}_{\mathrm{DUR}}$ had significantly

221 lower between-session CV than $\operatorname{MEP}_{\mathrm{REST}}(\mathrm{p}=0.002$ on related-samples Wilcoxon signed rank

222 test) but not $\operatorname{MEP}_{\text {ACTIVE }}(\mathrm{p}=0.019$ on related-samples Wilcoxon signed rank test), and

223 significantly higher between-session CV than RMT ( $p=0.004$ on related-samples Wilcoxon

224 signed rank test). In SCl participants, the CV was 28.50 (5.30) for SP DUR, 45.08 (6.90) for

$225 \mathrm{MEP}_{\mathrm{REST}}, 35.06$ (3.63) for MEP $\mathrm{ACTIVE}_{\text {, and }} 9.19$ (1.21) for RMT $(\mathrm{p}<0.0005$ on related-samples

226 Friedman's two-way analysis of variance by ranks test). Post hoc pairwise comparisons showed

227 that $\mathrm{SP}_{\mathrm{DUR}}$ had a non-significant trend toward lower between-session $\mathrm{CV}$ than MEP REST

228 ( $\mathrm{p}=0.086$ on related-samples Wilcoxon signed rank test), and no significant difference from

$229 \operatorname{MEP}_{\text {ACTIVE }}\left(p=0.314\right.$ on related-samples Wilcoxon signed rank test). SP $P_{\text {DUR }}$ had a trend toward

230 higher between-session CV than RMT ( $p=0.015$ on related-samples Wilcoxon signed rank test)

231 in SCl participants. There was no difference in between-session CV between $\mathrm{AB}$ and $\mathrm{SCl}$

232 participants. Thus, $\mathrm{SP}_{\text {DUR }}$ had significantly lower between-session variability than MEP

233 amplitudes in able-bodied but not SCI individuals. However, RMT values were clearly more

234 reliable across sessions than SP duration or MEP amplitudes.

$236 \quad 3.7$ SP Interruptions - 3 out of 12 AB participants and 8 out of 9 SCl participants showed

237 interrupted SPs ( $p=0.004$; Pearson chi-square test). Per session, AB volunteers showed 0.089

238 (0.71) interruptions, while $\mathrm{SCl}$ volunteers showed $1.781(0.787)$ interruptions $(p=0.001$ on 
medRxiv preprint doi: https://doi.org/10.1101/2020.06.07.20124701; this version posted November 2, 2020. The copyright holder for this preprint (which was not certified by peer review) is the author/funder, who has granted medRxiv a license to display the preprint in perpetuity. This article is a US Government work. It is not subject to copyright under 17 USC 105 and is also made available for use under a CCO license.

239 independent-samples Mann-Whitney $U$ test) (Figure 3). From the perspective of individual SP

240 trials, there were five interrupted CSPs out of 467 total CSP events (1.07\%) in AB participants, 241 and 52 interrupted CSPs out of 242 total CSP events (21.5\%) in SCI participants.

244 Discussion

245 The current study measured corticospinal excitatory and inhibitory pathways as reflected 246 by MEP amplitude and SP duration, respectively, in individuals with and without SCI. Our data 247 confirm the well-known finding that SCI individuals have higher TMS motor thresholds and lower 248 MEP amplitudes than able-bodied volunteers, indicating reduced excitability of the motor cortex, 249 reduced corticospinal transmission, reduced excitability of local spinal circuitry, or any 250 combination thereof. Due to large variability between individuals, we found no significant 251 difference in SP duration between SCl and able-bodied participants. Importantly, variability 252 within individuals of SP duration is lower than variability of MEP amplitude, suggesting that SP 253 duration may be a useful outcome measure with higher signal-to-noise ratio.

254 Appropriate movement requires inhibitory neural feedback as well as neural excitation.

255 Consequently, imbalance between neural excitation and inhibition may contribute to the failure 256 in restoration of useful motor function after SCI. Whereas MEP amplitude is usually regarded as 257 an excitatory readout and SP duration as an inhibitory readout, both measures reflect a complex 258 relationship between excitatory and inhibitory neurophysiology and clinical pathophysiology. A 259 prolonged SP has been reported in a number of cerebral pathologies such as stroke ${ }^{9}$, 
medRxiv preprint doi: https://doi.org/10.1101/2020.06.07.20124701; this version posted November 2, 2020. The copyright holder for this preprint (which was not certified by peer review) is the author/funder, who has granted medRxiv a license to display the preprint in perpetuity. This article is a US Government work. It is not subject to copyright under 17 USC 105 and is also made available for use under a CCO license.

260 epilepsy $^{10}$, and depression ${ }^{11}$. On the other hand, shortened SP duration has been reported in 261 bipolar disorder ${ }^{12}$, Parkinson's ${ }^{21}$, Alzheimer's disease ${ }^{22}$, and chronic neuropathic pain ${ }^{13}$.

262 Thus, lesions affecting the cortex, corticospinal tract, or segmental spinal circuits may 263 affect SP duration in opposing fashion. Further complicating the interpretation of SP duration, a 264 variety of experimental factors affect SP. In our study, we examined SP duration in the context 265 of a maximal-effort pincer grip between the thumb and third finger, with a relatively low TMS 266 intensity (110\% of RMT). SP duration correlates positively with increases in TMS intensity, but 267 does not correlate with level of volitional contraction ${ }^{3,23}$. SP duration is also highly task 268 dependent. In young adults, the fractionated task of abducting the index finger demonstrated 269 longer SP duration than a task involving pincer grip between the thumb and index finger, which 270 demonstrated longer SP duration than a task involving power grip ${ }^{24}$. This suggests an inverse 271 correlation between SP duration and the number of muscles used for a task ${ }^{4}$. Another study in 272 healthy adults showed that increasing amounts of sensory afferent input shortened SP 273 duration ${ }^{25}$. These studies demonstrated the importance of afferent feedback in downwardly 274 modulating SP duration, presumably by inhibiting the cortical GABAergic interneurons that 275 mediate $\mathrm{SP}^{15}$. Thus, SCl would be expected to prolong SP duration due to reduced afferent 276 feedback through the lesioned cord.

277 Our study did not show a significant difference in SP duration between SCI and $A B$ 278 participants. We speculate that the relatively low TMS intensity used in our study contributed to 279 shorter SP duration and increased variability between individuals, reducing sensitivity to detect 280 differences ${ }^{20}$. Prior investigation of SP in the SCI population has been limited. In six participants 281 after thoracolumbar SCI, SP duration in hand muscles above the lesion increased (APB muscle, 
medRxiv preprint doi: https://doi.org/10.1101/2020.06.07.20124701; this version posted November 2, 2020. The copyright holder for this preprint (which was not certified by peer review) is the author/funder, who has granted medRxiv a license to display the preprint in perpetuity. This article is a US Government work. It is not subject to copyright under 17 USC 105 and is also made available for use under a CCO license.

282 "gentle" pincer effort; TMS intensity at 140-180\% RMT), MEP amplitudes decreased, and 283 cortical motor map representations shifted ${ }^{14}$. The altered cortical maps in this study, as well as 284 the observed changes in muscles rostral to the spinal lesion level, suggested that these 285 neurophysiological changes after SCI were cortical in origin.

$286 \quad$ Likewise, a study of 16 participants with chronic cervical SCI relative to 18 uninjured 287 controls showed prolonged SP duration (FDI muscle, 25\% effort, TMS intensity set to produce 288 similar MEP amplitude across participants) after SCI, regardless of oral baclofen intake ${ }^{7}$. The 289 difference in SP duration seen by Barry and colleagues was observed when evoked by TMS but 290 not when evoked by transcranial electrical stimulation (TES) - since TMS activates corticospinal 291 neurons indirectly through cortical interneurons, this discrepancy between TMS and TES 292 pointed to cortical mechanisms for SP elongation after SCl. A study of nine males with chronic 293 cervical SCl observed prolonged SP (extensor digitalis communis muscle, 10\% effort, TMS 294 intensity at $110 \%$ AMT), increased motor thresholds, and shifted cortical maps relative to 295 uninjured controls ${ }^{16}$. Participants with greater spinal cord atrophy in that study showed relatively 296 greater changes in SP and motor thresholds, suggesting that corticospinal transmission and 297 local cord circuitry contributed to the observed neurophysiological changes.

298 On the contrary, a study of three individuals with cervical SCI showed loss of SP in two 299 of three hand muscles and all three foot muscles (50\% effort, TMS intensity at $100 \%$ of 300 stimulator output) ${ }^{17}$. The authors speculated that SP loss derived from abnormal ascending 301 sensory activity leading to cortical hyperexcitability, and/or increased local spinal neuronal 302 excitability. 
medRxiv preprint doi: https://doi.org/10.1101/2020.06.07.20124701; this version posted November 2, 2020. The copyright holder for this preprint (which was not certified by peer review) is the author/funder, who has granted medRxiv a license to display the preprint in perpetuity. This article is a US Government work. It is not subject to copyright under 17 USC 105 and is also made available for use under a CCO license.

Our findings of decreased coefficients of variation in SP duration relative to MEP

304 amplitude support the contention that SP duration may be a more reliable TMS metric than MEP

305 amplitude. One other study measured MEPs and SP across time in individuals with chronic

306 incomplete tetraplegia ${ }^{18}$. In that study, SP duration had relatively high reliability for both stronger

307 and weaker muscles, whereas MEP amplitude had medium reliability for stronger muscles and

308 poor reliability for weaker muscles. Studies in able-bodied participants provide further evidence

309 that SP duration is more reliable across sessions than between individuals ${ }^{20}$. Importantly,

310 resting motor threshold, which is determined at the beginning of any experimental TMS session,

311 showed the least between-session variability of the measures we examined. Resting motor

312 threshold demonstrated the lowest variability of multiple TMS measures in a study of elderly

313 individuals with and without stroke ${ }^{26}$. It remains to be determined whether motor threshold is

314 more sensitive than other measures to detecting changes after interventions aimed to increase

315 central neural transmission in people with SCI.

316 We observed an overwhelmingly higher prevalence of SP 'interruption' frequency in SCl

317 relative to $A B$ participants. These short $(<20 \mathrm{~ms})$ periods of EMG activity in the midst of the SP

318 appear similar to 'late excitatory potentials (LEP)' noted by Wilson et $\mathrm{al}^{27}$ and 'breakthrough

319 EMG activity' discussed by Hupfeld at $\mathrm{al}^{4}$. Intra-SP EMG activity has been hypothesized to

320 originate from two sources: muscle spindle-gamma motoneuron reflex activity in response to

321 muscle lengthening during the SP; and transient cortical disinhibition ${ }^{27}$. Caudal to the lesion,

322 increased spindle-mediated reflex activity is well documented after SCI. At the lesion,

323 fasciculations of individual motor units represent spontaneous hyperexcitable discharges in 
medRxiv preprint doi: https://doi.org/10.1101/2020.06.07.20124701; this version posted November 2, 2020. The copyright holder for this preprint

(which was not certified by peer review) is the author/funder, who has granted medRxiv a license to display the preprint in perpetuity.

This article is a US Government work. It is not subject to copyright under 17 USC 105 and is also made available for use under a CCO license.

324 upper extremity muscles commonly seen after cervical $\mathrm{SCl}^{28}$. Therefore, it is not surprising that

325 SCI participants demonstrated a much higher SP interruption rate than AB participants.

326 Our study has several important limitations: Due to time constraints, only 5-6 SP trials

327 were collected per session, less than the roughly 20 trials needed to maximize reliability of most

328 TMS measures ${ }^{4,29}$. The SCI group was older than the control group. A majority of past studies

329 suggest that age negatively correlates with SP duration, which would mean that the results of

330 this study may underestimate the true difference in SP duration between $\mathrm{SCl}$ and non-SCI

331 groups ${ }^{4}$. Individuals in the $\mathrm{SCl}$ group were more likely to be taking oral baclofen or other neural

332 inhibitory medications. However, unlike intrathecal baclofen, oral baclofen has not clearly been

333 shown to affect SP duration ${ }^{7,8}$. Furthermore, individuals with SCI have obviously lower ability to

334 contract target muscles than non-SCI participants during SP elicitation. However, this would be

335 the case whether at maximal effort or at any set percentage of an individual's volitional effort,

336 and muscle contraction intensity does not play a major role in SP duration regardless ${ }^{3,23}$. TMS

337 intensity during SP measurements was at $110 \%$ of resting motor threshold - most studies have

338 used higher TMS intensities, which is a key factor in longer SP duration and may reduce

339 intersession variability ${ }^{3,20,23}$.

341 Conclusion

342 In individuals with chronic cervical SCI relative to able-bodied controls, we confirmed the

343 well-known findings that SCI individuals have lower TMS evoked potential amplitudes and a

344 tendency toward higher TMS motor thresholds. We did not observe significantly longer SP

345 duration in SCI individuals. Importantly, we observed significantly lower within-person variability 
medRxiv preprint doi: https://doi.org/10.1101/2020.06.07.20124701; this version posted November 2, 2020. The copyright holder for this preprint

(which was not certified by peer review) is the author/funder, who has granted medRxiv a license to display the preprint in perpetuity.

This article is a US Government work. It is not subject to copyright under 17 USC 105 and is also made available for use under a CCO license.

346 of SP duration than within-person variability of TMS response amplitude, suggesting that SP

347 duration may be a useful outcome measure with higher signal-to-noise ratio. Ongoing and future

348 studies in our lab will further investigate silent periods induced by either cortical or cutaneous

349 stimulation $^{30}$ to correlate EMG with electroencephalographic features and shed more

350 mechanistic insight into these phenomena.

352 Data Archiving: Individual-level data is included as Supplementary Data 1 (by participant,

353 averaged across sessions) and Supplementary Data 2 (by participant per session). All

354 deidentified data is freely available to any investigator upon request.

356 Statement of Ethics: All procedures were approved by the Institutional Review Board of the

357 James J. Peters VA Medical Center, Bronx, NY (HAR-15-001). We certify that all applicable

358 institutional and governmental regulations concerning the ethical participation of human

359 volunteers were followed during the course of this research.

361 Conflicts of Interest: The authors declare no conflicts of interest.

363 Author Contributions:

364 HJS: Data acquisition; data interpretation; manuscript drafting and revision

365 JRW: Data acquisition; data interpretation; manuscript drafting and revision 
medRxiv preprint doi: https://doi.org/10.1101/2020.06.07.20124701; this version posted November 2, 2020. The copyright holder for this preprint

(which was not certified by peer review) is the author/funder, who has granted medRxiv a license to display the preprint in perpetuity.

This article is a US Government work. It is not subject to copyright under 17 USC 105 and is also made available for use under a CCO license.

366 OA: Data interpretation; manuscript revision

367 YKW: Data acquisition; data interpretation; manuscript revision

368 NYH: Study conception and design; data interpretation; manuscript drafting and revision.

370 Sources of Funding: New York State Department of Health C30599. Craig H. Neilsen

371 Foundation 457648. 


\section{References}

375 1. Fuhr, P., Agostino, R. \& Hallett, M. Spinal motor neuron excitability during the silent

376 period after cortical stimulation. Electroencephalogr. Clin. Neurophysiol. Evoked

$377 \quad$ Potentials 81, 257-262 (1991).

378 2. Poston, B., Kukke, S. N., Paine, R. W., Francis, S. \& Hallett, M. Cortical silent period

379 duration and its implications for surround inhibition of a hand muscle. Eur. J. Neurosci.

$380 \quad 36,2964-2971(2012)$.

381 3. Inghilleri, M., Berardelli, A., Cruccu, G. \& Manfredi, M. Silent period evoked by

382 transcranial stimulation of the human cortex and cervicomedullary junction. J. Physiol.

$383 \quad 466,521-534(1993)$.

384 4. Hupfeld, K. E., Swanson, C. W., Fling, B. W. \& Seidler, R. D. TMS-induced silent periods:

385 A review of methods and call for consistency. Journal of Neuroscience Methods 346,

386 (2020).

387 5. Inghilleri, M., Berardelli, A., Marchetti, P. \& Manfredi, M. Effects of diazepam, baclofen

388 and thiopental on the silent period evoked by transcranial magnetic stimulation in

389 humans. Exp. Brain Res. 109, 467-472 (1996).

390 6. Stetkarova, I. \& Kofler, M. Differential effect of baclofen on cortical and spinal inhibitory

$391 \quad$ circuits. Clin. Neurophysiol. 124, 339-345 (2013).

392 7. Barry, M. D., Bunday, K. L., Chen, R. \& Perez, M. A. Selective effects of baclofen on use393 dependent modulation of GABAB inhibition after tetraplegia. J. Neurosci. 33, 12898-907

394 (2013). 
8. McDonnell, M. N., Orekhov, Y. \& Ziemann, U. The role of GABAB receptors in intracortical inhibition in the human motor cortex. Exp. Brain Res. 173, 86-93 (2006).

9. Braune, H. J. \& Fritz, C. Transcranial magnetic stimulation-evoked inhibition of voluntary muscle activity (silent period) is impaired in patients with ischemic hemispheric lesion. Stroke 26, 550-553 (1995).

10. Macdonell, R. A. et al. Prolonged cortical silent period after transcranial magnetic stimulation in generalized epilepsy. Neurology 57, 706-8 (2001).

11. Steele, J. D., Glabus, M. F., Shajahan, P. M. \& Ebmeier, K. P. Increased cortical inhibition in depression: A prolonged silent period with transcranial magnetic stimulation (TMS). Psychol. Med. 30, 565-570 (2000).

12. Levinson, A. J., Young, L. T., Fitzgerald, P. B. \& Daskalakis, Z. J. Cortical inhibitory dysfunction in bipolar disorder: A study using transcranial magnetic stimulation. J. Clin. Psychopharmacol. 27, 493-497 (2007).

13. Lefaucheur, J. P., Drouot, X., Ménard-Lefaucheur, I., Keravel, Y. \& Nguyen, J. P. Motor

411 14. Lotze, M., Laubis-Herrmann, U. \& Topka, H. Combination of TMS and fMRI reveals a specific pattern of reorganization in $\mathrm{M} 1$ in patients after complete spinal cord injury. Restor Neurol Neurosci 24, 97-107 (2006).

414 15. Nardone, R. et al. Motor cortex excitability changes following a lesion in the posterior 415 columns of the cervical spinal cord. Neurosci. Lett. 434, 119-123 (2008).

416 16. Freund, P., Rothwell, J. C., Craggs, M., Thompson, A. J. \& Bestmann, S. Corticomotor 
representation to a human forearm muscle changes following cervical spinal cord injury.

419 17. Shimizu, T., Hino, T., Komori, T. \& Hirai, S. Loss of the muscle silent period evoked by transcranial magnetic stimulation of the motor cortex in patients with cervical cord lesions. Neurosci. Lett. 286, 199-202 (2000).

18. Potter-Baker, K. A. et al. Reliability of TMS metrics in patients with chronic incomplete spinal cord injury. Spinal Cord 54, 980-990 (2016).

19. Wu, Y.-K. et al. Posteroanterior cervical transcutaneous spinal stimulation targets ventral

427 20. Orth, M. \& Rothwell, J. C. The cortical silent period: Intrinsic variability and relation to the waveform of the transcranial magnetic stimulation pulse. Clin. Neurophysiol. 115, 1076-

430 21. Nakashima, K., Wang, Y., Shimoda, M., Sakuma, K. \& Takahashi, K. Shortened silent period produced by magnetic cortical stimulation in patients with Parkinson's disease. J.

433 22. Alagona, G. et al. Transcranial magnetic stimulation in Alzheimer disease: Motor cortex 434 excitability and cognitive severity. Neurosci. Lett. 314, 57-60 (2001).

435 23. Kojima, S. et al. Modulation of the cortical silent period elicited by single- and paired436 pulse transcranial magnetic stimulation. BMC Neurosci. 14, (2013).

437 24. Tinazzi, M. et al. Task-dependent modulation of excitatory and inhibitory functions within 438 the human primary motor cortex. Exp. Brain Res. 150, 222-229 (2003). 
439 25. Hess, A. et al. Task-dependent modulation of inhibitory actions within the primary motor $440 \quad$ cortex. Exp. Brain Res. 124, 321-330 (1999).

441 26. Schambra, H. M. et al. The reliability of repeated TMS measures in older adults and in 442 patients with subacute and chronic stroke. Front. Cell. Neurosci. 9, (2015).

443 27. Wilson, S. A., Thickbroom, G. W. \& Mastaglia, F. L. An investigation of the late excitatory 444 potential in the hand following magnetic stimulation of the motor cortex.

445 Electroencephalogr. Clin. Neurophysiol. Electromyogr. 97, 55-62 (1995).

446 28. Grapperon, A. M. \& Attarian, S. Disorders of motor neurons manifested by hyperactivity. 447 Revue Neurologique 173, 345-351 (2017).

448 29. Nguyen, D. T. A., Rissanen, S. M., Julkunen, P., Kallioniemi, E. \& Karjalainen, P. A. 449 Principal Component Regression on Motor Evoked Potential in Single-Pulse Transcranial 450 Magnetic Stimulation. IEEE Trans. Neural Syst. Rehabil. Eng. 27, 1521-1528 (2019).

451 30. Tadokoro, N. et al. Discrepancy between functional recovery and cutaneous silent period 452 change in surgically treated degenerative cervical myelopathy: a prospective pilot study. $453 \quad$ Spinal Cord 57, 1076-1083 (2019). 
medRxiv preprint doi: https://doi.org/10.1101/2020.06.07.20124701; this version posted November 2, 2020. The copyright holder for this preprint

(which was not certified by peer review) is the author/funder, who has granted medRxiv a license to display the preprint in perpetuity.

This article is a US Government work. It is not subject to copyright under 17 USC 105 and is also made available for use under a CCO license.

\section{Legends}

457 Figure 1 - Schematic and examples of silent period. A) TMS is delivered (red arrow) to the

458 hand motor cortex while the participant performs a volitional isometric pinch with the 459 contralateral hand. The resulting MEP (black arrow) is followed by an EMG silent period before 460 the resumption of baseline volitional EMG activity. B) Representative silent period in able-

461 bodied volunteer. C) Representative silent period in SCI participant. Note lower EMG 462 amplitudes and presence of 'interruption' (green arrow). APB, abductor pollicis brevis.

464 Figure 2 - Outcome variability. A) Within-session coefficient of variation for each group. B) 465 Between-session coefficient of variation for each group. Error bars represent S.E.M. *, 466 significantly different from SP duration; ¥, significantly different from RMT.

468 Figure 3 - SP interruptions by group and participant. The average number of interruptions 469 per session for each participant. Error bars represent S.D.

471 Supplementary Data 1 - Participant-level data averaged across sessions.

472 InterssNum, number of interruptions per session; CVSPdurlntra, intrasession coefficient of

473 variation for $\mathrm{SP}_{\mathrm{DUR}}$; CVMEPrestlntra, intrasession coefficient of variation for MEP $\mathrm{REST}_{\text {; }}$

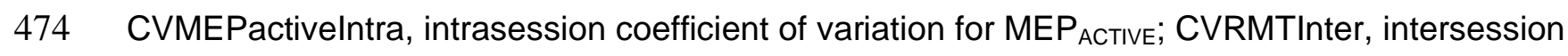
475 coefficient of variation for RMT; CVSPdurlnter, intersession coefficient of variation for $\mathrm{SP}_{\mathrm{DUR}}$; 
medRxiv preprint doi: https://doi.org/10.1101/2020.06.07.20124701; this version posted November 2, 2020. The copyright holder for this preprint (which was not certified by peer review) is the author/funder, who has granted medRxiv a license to display the preprint in perpetuity.

This article is a US Government work. It is not subject to copyright under 17 USC 105 and is also made available for use under a CCO license.

476 CVMEPrestlnter, intersession coefficient of variation for MEP $\mathrm{REST}$; CVMEPactivelnter,

477 intersession coefficient of variation for MEP ACTIVE.

478

479 Supplementary Data 2 - Participant-level data listed per session.

480

481

482

483 
A

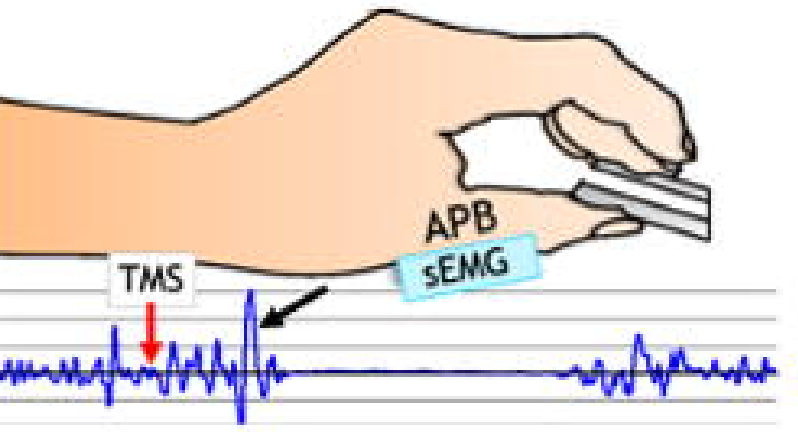

B

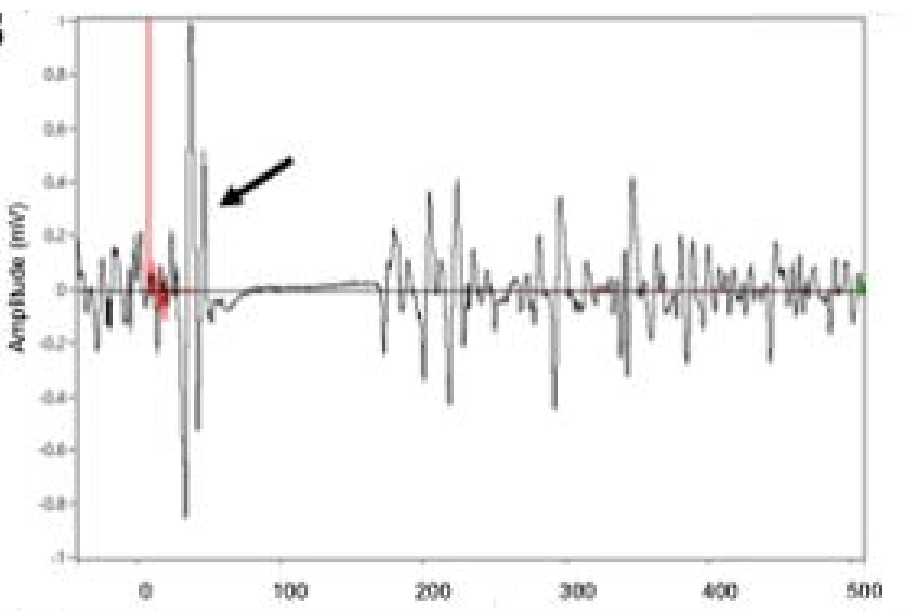

c

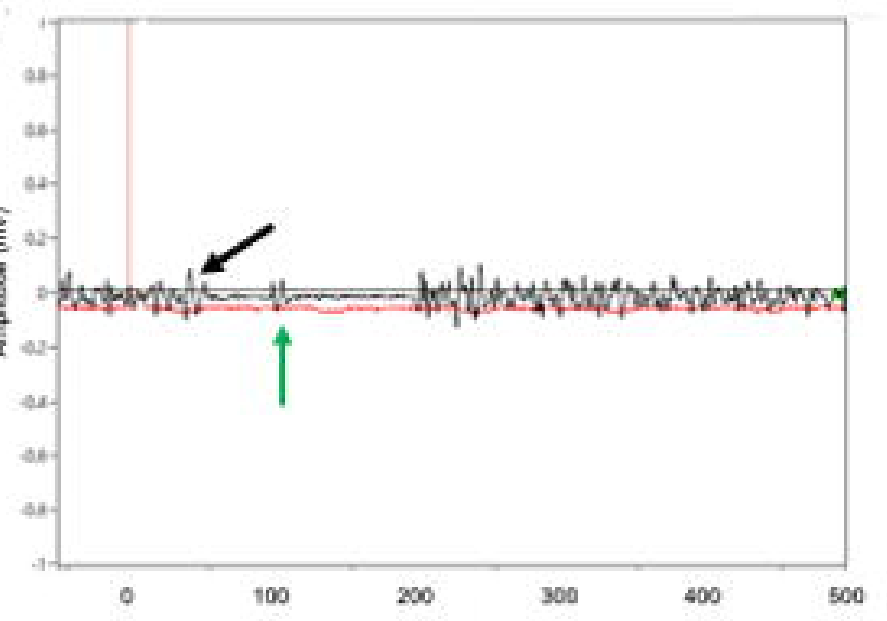

The (ma) 
A

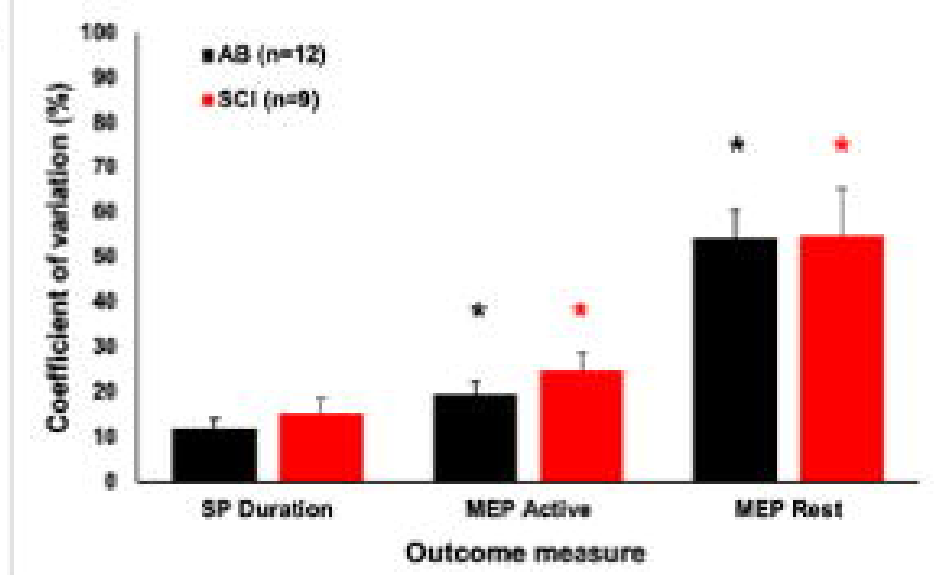

B

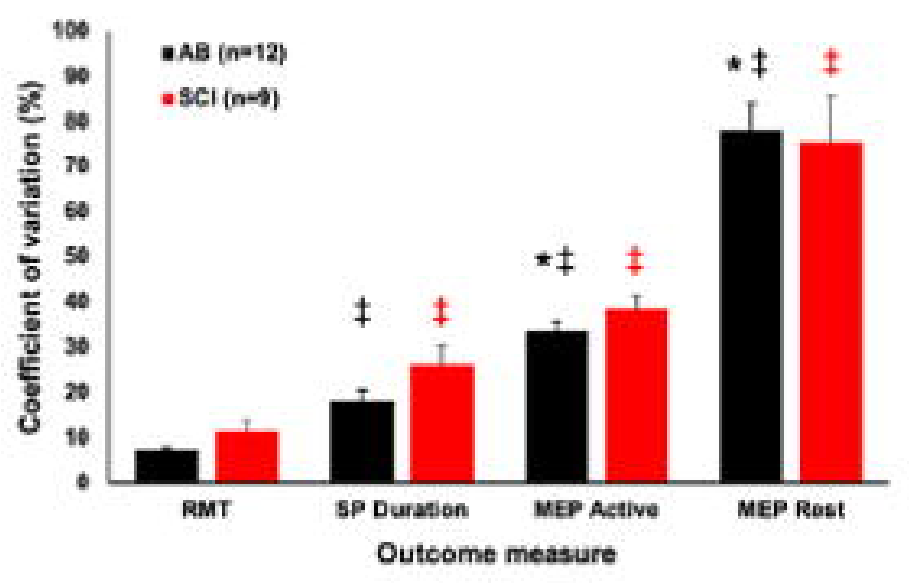


$\begin{array}{ll}\frac{5}{5} & = \\ \frac{5}{5} & 4 \\ \frac{5}{5} & 2 \\ \frac{5}{5} & 1 \\ \frac{5}{5} & 1\end{array}$

e

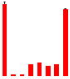

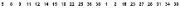

Pertecalicelgec Tabo 1 | 